\title{
STRATEGI PENGEMBANGAN PRODUK PARIWISATA KREATIF BERBASIS POTENSI SUMBER DAYA ALAM DAN KEARIFAN LOKAL DESA WISATA
}

\author{
Nawangsih \\ Program Studi Manajemen, STIE Widya Gama Lumajang \\ Email:lovinawang@gmail.com
}

\begin{abstract}
The field of tourism became one of the sectors that received much attention, given the multidimensional arising from various other things, most important for his followers. The purpose of this study is to knowing about creative tourism product and to knowing the potential natural resource and the local wisdom of villagers of tourism. The research type is qualitative descriptive research, using phenomenology approach. Data collected use interviews, interviews and document studies. The results show that tourism development strategies for creative tourism product, using various media both online and offline, using bazaar events, cultural festivals and activities related to community and village. The potential of natural resources and forms of wisdom used by the tourist villages are very diverse, among others: kebuang tourism, waterfall tours, adventure nature tourism and other types of nature tourism, while the local wisdom form other tourist villages: celebration of spell, ronang event, carnival villages, village alms and other tourist and local wisdom events. Research recommendation is the activity need to regeneration to obersve culture tourism to became development from generation to generation to support development village tourism
\end{abstract}

Key word : development strategy, natural resource, local wisdom and tourism village

Abstrak. Bidang pariwisata menjadi salah satu sektor yang banyak mendapatkan perhatian, mengingat dampak multidimensi yang ditimbulkan dari bidang tersebut kepada bidang yang lainnya, yang berperan penting bagi peningkatan perekonomian masyarakat sekitar. Tujuan penelitian ini adalah untuk mengetahui strategi pengembangan produk pariwisata kreatif dan untuk mengetahui potensi sumber daya alam dan kearifan lokal yang dimiliki desa wisata. Jenis penelitian adalah penelitian deskriptif kualitatif, dengan menggunakan pendekatan fenomenologi. Tekhnik pengumpulan data menggunakan wawancara, observasi dan studi dokumen. Hasil penelitian menunjukkan bahwa strategi pengembangan produk wisata kreatif, yang dikembangkan desa wisata, dengan menggunakan berbagai media online maupun offline, memanfaatkan event bazar, festival budaya dan kegiatan yang erat kaitannya dengan pariwisata dan kearifan lokal masyarakat desa. Potensi sumber daya alam dan bentuk kearifan lokal yang dimiliki oleh desa wisata sangat beragam, antara lain : wisata kebuh teh, wisata air terjun, wisata alam adventure dan jenis wisata alam lainnya, sedangkan bentuk kearifan lokal desa wisata antara lain : festifal ujung mantra, event ronang, karnaval desa, sedekah desa dan event wisata dan kearifan lokal lainnya. Rekomendasi penelitian : perlu adanya kegiatan regenerasi untuk pelestarian wisata budaya agar bisa dikembangkan dari generasi ke generasi, untuk pengembangan desa wisata

Kata Kunci: strategi pengembangan, sumber daya alam, kearifan lokal, desa wisata 


\section{PENDAHULUAN}

Pariwisata adalah salah satu bidang yang mendapat perhatian serius dari pemerintah. Program pemerintah daerah Kabupaten Lumajang, dengan kebijakan 1 Kecamatan, 1 desa wisata dan 1 sentra batik, memberikan pengaruh positif bagi masing-masing daerah dalam mengeksplorasi potensi yang dimiliki baik secara buatan maupun alami. Salah satunya terletak di Gucialit sekitar $25 \mathrm{~km}$ ke arah barat dari Kabupaten Lumajang. Kondisi desa ini terletak di daerah dataran tinggi, dengan hawa yang sejuk dan pemandangan alam yang alami, menjadi daya tarik tersendiri bagi wisatawan yang berkunjung ke desa tersebut. Program pemerintah untuk menjadikan desa ini sebagai desa wisata membutuhkan kerja sama dan sinergitas lintas bidang dengan semua pihak yang terlibat di dalamnya.

Menciptakan sebuah desa wisata dengan mengedepankan produk pariwisata kreatif dilakukan dengan memberdayakan masyarakat melalui kegiatan UMKM untuk menciptakan produk kreatif dengan memanfaatkan potensi sumber daya alam dan kearifan lokal yang dimiliki. Laporan dari UNESCO (2006) mengindikasikan bahwa pariwisata kreatif merupakan generasi baru pariwisata. Pendekatan budaya melalui nilai kearifan lokal tealh merubah bentuk pariwisata kreatif yang dihasilkan (Ohridska-Olson \& Ivanov, 2010). Pengembangan konsep pariwisata kreatif sebagai solusi efektif menawarkan bentuk pariwisata yang berbeda kepada wisatawan. Produk pariwisata kreatif berbasis potensi sumber daya alam dan nilai kearifan lokal memberikan kesempatan dan ruang baru bagi desa untuk mengeksplorasi potensi yang dimiliki, terutama melalui produk industri kreatif dan keunikan identitas lokal yang dimiliki dalam bentuk nilai kearifan lokal (Kostopoulou, 2013). Pariwisata kreatif mengandung 5 elemen penting yaitu : permintaan, penawaran, serta manfaatnya baik secara nyata maupun tidak nyata, dan manfaat secara finansial sebagai daerah tujuan wisata, (Ohridska-Olson \& Ivanov, 2010).

Berdasarkan latar belakang tersebut, maka kemampuan dalam menetapkan strategi pengembangan produk pariwisata kreatif berbasis potensi sumber daya alam dan kearifan lokal menjadi hal yang pentig dalam menujang keberhasilan desa wisata. Oleh karena itu maka tujuan penelitian yang ingin dicapai adalah sebagai berikut :

1. Untuk mengetahui strategi pengembangan produk pariwisata kreatif

2. Untuk mengetahui potensi sumber daya alam dan kearifan lokal yang dimiliki desa wisata.

\section{KAJIAN TEORI \\ Strategi}

Strategi adalah cara dan alat yang digunakan untuk mencapai tujuan akhir (sasaran atau objective). Strategi harus mampu membuat semua bagian saling berkaitan satu dengan yang lain yang luas menjadi satu, terpadu untuk mencapai tujuan akhir (sasaran atau objective). Prawironegoro dan Rivai (2015:9)

\section{Faktor Pendorong Perkembangan Pariwisata}

Faktor pendorong wisatawan melakukan perjalan wisata, menurut (Muljadi, 2014), antara lain : adanya waktu libur atau waktu luang yang dimiliki wisatawan, pendapatan masyarakat yang meningkat, perkembangan tekhnologi informasi, tingkat pendidikan masyarakat, pola kerja dalam era persaingan yang kompetitif, perjalanan dalam kaitannya dengan pekerjaan, wisata dan kegiatan pemasaran pariwisata seuatu daerah 


\section{Produk Pariwisata Kreatif}

Produk pariwisata diwujudkan dalam bentuk fasilitas dan pelayanan yang diberikan kepada wisatawan, yang terdiri dari 3 komponen utama yaitu : sumber daya pendukung daerah tujuan wisata, fasilitas dan sarana transportasi yang dimiliki, (Yoeti, 2008:128)

\section{Potensi Sumber Daya Alam dan Kearifan Lokal}

Potensi Sumber Daya Alam : yang dimiliki terkait dengan kondisi Sumber Daya Alam yang dimiliki oleh suatu daerah, dan Kearifan lokal sebagai warisan nenek moyang dalam tata nilai kehidupan menyatu dalam bentuk religi, budaya dan adat istiadat. Kearifan lokal adalah praktik yang dikembangkan oleh sekelompok masyarakat yang berasal dari pemahaman mendalam terhadap lingkungan dan kondisi setempat yang terbentuk secara turun menurun, Fathiyah dan Hiryanto (2010:120).

\section{Desa Wisata}

Desa wisata dijadikan solusi alternatif bagi upaya pengembangan obyek wisata konvensiaonal. Desa wisata adalah bentuk pengembangan sebuah desa menjadi distinasi wisata dengan sistem pengelolaan yang bersifat, dari, oleh, dan untuk masyarakat, (Bashori Imron, 2014)

\section{METODE PENELITIAN}

Lokasi penelitian ini terletak di Desa Gucialit, Kecamatan Gucialit, Kabupaten Lumajang. Penentuan informan penelitian menggunakan metode purposive sampling, yaitu cara penentuan informan yang berdasarkan atas tujuan tertentu dan atas pertimbangan peneliti (Sugiyono, 2014). Teknik pengumpulan data dalam penelitian ini dilakukan dengan observasi, wawancara, studi kepustakaan, dan dokumentasi. Data yang terkumpul dianalisis menggunakan model deskriptif kualitatif. Informan penelitian terdiri dari : Kelompok Sadar Wisata (POKDARWIS) Desa Gucialit, Kecamatan Guciliat, Gucialit Organisasi Wisata Alam, pelaku usaha dan masyarakat.

\section{HASIL DAN PEMBAHASAN \\ Strategi Pengembangan Produk Pariwisata Kreatif}

Hasil wawancara dan observasi di lapangan menunjukkan bahwa strategi pengembangan dilakukan dengan menggunakan melalui web dari Kelompok Sadar Wisata (POKDARWIS) terkait dengan potensi pariwisata yang ada di desa wisata, melakukan kegiatan promosi dengan memanfaatkan media online dan offline, mengadakan berbagai event wisata, membuat lomba produk antar UMKM lokal, melakukan inovasi untuk berbagai kegiatan atraksi wisata dan produk kreatif lokal, sehingga menjadi sumber pendapatan bagi masyarakat sekitar. Hasil kegiatan wawancara tentang strategi pengembangan produk pariwisata kreatif, yang dilakukan memberikan informasi sebagai berikut:

Pendapat informan penelitian ke 1 (Kelompok Sadar Wisata/POKDARWIS), tentang strategi yang digunakan untuk mengembangkan produk wisata kreatif sudah dilakukan dengan berbagai macam cara dengan maksud agar potensi atau nilai lebih destinasi wisata di desa wisata bisa lebih dikenal oleh masyarakat secara luas, seperti yang dikemukakan informan di bawah ini :

..."Upaya yang dilakukan Pokdarwis untuk mengembangkan produk wisata kreatif, dilakukan dengan berbagai macam cara, misalnya : mempromosikan potensi menggunakan media online dan offline, mengadakan event atraksi wisata yang menarik, misalnya pemilihan cak yuk untuk duta wisata lumajang, 
membuat lomba produk antar UMKM sebagai produk icon unggulan desa, untuk memotivasi desa agar mampu mengeksplorasi potensi dan nilai lebih, yang dimiliki masing..."

Pendapat informan penelitian ke 2 (Gucialit Organisasi Wisata Alam (GOWA), terkait dengan strategi pengembangan wisata alam khususnya produk pariwisata kreatif dilakukan dalam bentuk edukasi bank sampah, pembuatan produk kaos dengan mengangkat tema desa tersebut, dan pembuatan aneka jenis aksesoris menarik sebagai oleh-oleh dari desa tersebut, seperti yang dikemukakan oleh informan sebagai berikut:

.." Strategi pengembangan produk pariwisata kreatif salah satunya dalam bentuk kegiatan pelatihan pembuatan kerajinan daur ulang sampah dari kelompok Gucialit Edukasi Sampah (GUESA), pembuatan produk chloting line kaos tematik, aneka jenis topi, gantungan kunci dengan obyek Gucialit sebagai sumber ide kreatifnya, pembuatan kopi Gucialit dan masih banyak lagi kegiatan lainnya,..."

Pendapat informan penelitian ke 3 (Kecamatan Gucialit), tentang cara memperkenalkan Gucialit sebagai desa wisata, dilakukan dengan cara pembuatan icon desa wisata, pembuatan web dan menyelenggarakan event wisata dan lain sebagainya, seperti yang dikemukakan oleh informan, sebagai berikut :

..."Rencana pengembangan pariwisata yang dilakukan oleh pemerintah daerah, misalnya : pembuatan identitas dan icon Gucialit sebagai desa wisata, pelestarian kesenian dan kearifan lokal desa, pembuatan web untuk promosi pariwisata desa, dan menyelenggarakan berbagai event kegiatan pariwisata, termasuk agrowisata, dengan keunggulan wisata alam, wisata sejarah, wisata edukasi dan lain-lain..."

Pendapat informan ke 4 (Pelaku usaha), terkait dengan jenis produk kreatif yang dikembangkan di desa tersebut, antara lain, sebagai berikut :

..."Produk industri kreatif yang dikembangkan sebagian besar dalam bentuk Usaha Mikro Kecil Menengah (UMKM), dilakukan ibu rumah tangga, misalnya pembuatan batik, teh manten, keripik pisang, pembuatan makanan tradisional khas Gucialit dan masih banyak lagi produkyang lainnya..."

Pendapat informan ke 5 (Masyarakat), terkait dengan respon masyarakat terhadap rencana pemerintah desa untuk menjadikan Gucialit sebagai desa wisata, sebagai berikut :

..."Rencana Gucialit sebagai desa wisata didukung masyarakat, sehingga banyak masyarakat yang tertarik memanfaatkan peluang ini, dengan membuka usaha, karena menguntungkan..."

Permasalahan yang dihadapi dalam pengembangan desa wisata, antara lain seperti yang dikemukakan oleh beberapa informan sebagai berikut:

Pendapat informan penelitian ke 2 (Gucialit Organisasi Wisata Alam (GOWA), terkait dengan pentingnya kegiatan regenerasi bagi pelaku atau penggiat seni agar kesenian yang menjadi ciri khas desa tersebut dapat dilestarikan, sebagai berikut :

..."Untuk kegiatan kesenian di desa ini butuh perhatian yang lebih karena, khususnya untuk kesenian tradisional khas desa seperti ronang dan ujung, pelaku atau penggiat seni adalah generasi tua, generasi muda masih banyak yang belum berminat untuk menekuni dalam bidang ini, sehingga dibutuhkan regenarasi agar kesenian tersebut tidak punah.."

Pendapat lainnya tentang hambatan terkait pengembangan desa wisata, dari sisi masyarakat dan kesiapan masyarakat dalam menjadikan Gucialit sebagai desa wisata, juga dikemukakan oleh informan ke 3 (Gucialit Organisasi Wisata Alam (GOWA) sebagai berikut: 
..."Perlu adanya sosialisasi yang lebih intens kepada masyarakat untuk bisa bekerja bersama-sama dalam mensukseskan rencana pengembangan desa wisata, misalnya dengan bersikap ramah, santun dan menjaga kenyamanan wisatawan selama berada di lokasi tersebut.."

\section{Potensi Sumber Daya Alam dan Kearifan Lokal yang Dimiliki Desa Wisata.}

Hasil wawancara dan observasi di lapangan menunjukkan bahwa potensi Sumber Daya Alam dan kearifan lokal yang dimiliki desa wisata, cukup beragam, antara lain : potensi Sumber Daya Alam dalam bentuk wisata perbukitan, wisata kebun teh, wisata air terjun, wisata edukasi dan wisata minat khusus sedangkan bentuk kearifan lokal yang dimiliki oleh desa wisata Gucialit, antara lain : kesenian ronang, ujung mantra, karnaval desa, bersih desa, sedekah desa serta masih terjaga kelestarian bentuk bangunan peninggalan Belanda sebagai sarana rekreasi dan bentuk pemukiman penduduk yang bekerja di PTPN XII Kertowono.

Hasil kegiatan wawancara tentang, potensi Sumber Daya Alam dan kearifan lokal yang dimiliki desa wisata yang dilakukan memberikan informasi sebagai berikut:

Pendapat informan ke 1 (POKDARWIS), terkait dengan beragamnya potensi alam yang dikembangkan di desa tersebut untuk menunjang keberagaman destinasi wisata yang menarik untuk dikunjungi, antara lain sebagai berikut :

..." Sumber Daya Alam yang dimiliki di desa wisata Gucialit, antara lain : wisata alam kebun teh dengan aktifitas pemetik teh di pagi hari, Bukit Kampung Baru (KBR) atau bukit inspirasi, Bukit 74 (B74) yang termasuk daerah Afdeling Kertosuko, bukit 1001 keberadaan bukit tersebut di ketinggian 1001 meter di atas permukaan laut/mdpl, bukit yang pada era Hindia Belanda merupakan pos pemantau untuk mengawasi pemetik teh yang bekerja, wisata air terjun Perre, wisata sungai Kali Gadang, wisata air terjun Curah Bedug, serta nuansa alam di daerah Perhutani..."

Pendapat informan ke 2 (Gucialit Organisasi Wisata Alam (GOWA), terkait adanya potensi wisata edukasi dan minat khusus sebagai nilai lebih Gucialit sebagai desa wisata, adalah sebagai berikut:

..."Potensi sumber daya alam yang dimiliki desa wisata Gucialit, cukup banyak, misalnya: selain pemandangan alam yang menarik juga memiliki wisata sejarah dengan adanya bangunan kolonial Belanda yang berumur puluhan tahun, untuk disewakan kepada wisatawan baik lokal maupun mancanegara yang berkunjung ke lokasi tersebut. Desa wisata Gucialit juga memiliki wisata edukasi dan minat khusus yaitu proses pembuatan teh dari awal hingga menjadi produk teh kelas dunia di Pabrik PTPN XII Kebun Kertowono, Kecamatan Gucialit, wisatawan dapat melihat proses pembuatan teh dan belajar mengenal kualitas teh yang diolah dalam bentuk bubuk kasar menjadi minuman yang siap untuk dinikmati, dengan ditemani para ahli peracik teh kita mendapatkan pengetahuan baru mengenai kualitas dan cara menyajikan serta mencoba sensasi teh kualitas dunia..."

Pendapat informan ke 3 (Kecamatan Gucialit), terkait kearifan lokal yang masih dipertahankan sebagai ciri khas dari perumahan perkebunan dengan karakteristik yang unik di masing-masing daerah, adalah sebagai berikut :

..."Kearifan lokal masyarakat disini diwujudkan dalam bentuk aktifitas keseharian masyarakat bekerja sebagai buruh pemetik teh di PTPN XII Kertowono, bentuk perumahan khas jaman kolonial yang dijaga bentuk keasliandan ciri khasnya yang terletak di kawasan Perumahan Semingkir menjadi daya tarik berbeda dari destinasi wisata Kecamatan Gucialit, seni dan tradisi secara turun menurun dalam bentuk bersih desa, sedekah desa, tarian ronang, tarian ujung mantra dan masih banyak lagi yang lain..." 
Pendapat informan ke 4 (Pelaku usaha), memanfaatkan potensi wisata yang dimiliki sebagai peluang dalam berwirausaha, antara lain, sebagai berikut :

..."Alam desa Gucialit memang indah apalagi keberadaan agrowisata yang baru saja dibuka oleh PTPN XII, menjadikan obyek wisata baru yang menarik banyak orang untuk datang ke sini, sehingga banyak masyarakat yang membuka usaha dengan memanfaatkan kesempatan adanya agrowisata salah satunya dengan menjual produk khas yang dimiliki yaitu teh, kopi dan beragam makanan tradisional di desa tersebut ..."

Pendapat informan ke 5 (Masyarakat), tentang bentuk kearifan lokal yang dimiliki di desa wisata Gucialit, sebagai bentuk nilai tradisi masyarakat yang harus dijaga kelestariannya, adalah sebagai berikut:

..."Ketika ada acara festifal tari ujung mantra dan ronang, banyak orang berkunjung ke desa ini, termasuk acara karnaval desa, sedekah desa yang menjadi tradisi dan sudah berlangsung lama secara turun temurun, masyarakat antusias sekali menyaksikan acara tersebut..."

Permasalahan yang dihadapi dalam mengembangkan potensi pariwisata kreatif, dan kearifan lokal masyarakat, antara lain seperti yang dikemukakan oleh beberapa informan sebagai berikut:

Pendapat informan penelitian ke 2 (Gucialit Organisasi Wisata Alam (GOWA), tentang kendala berupa sarana dan prasana pendukung sebuah obyek wisata agar layak dan menarik untuk dikunjungi, yaitu sebagai berikut :

..."Banyak potensi desa wisata yang bisa dieksplorasi agar bisa dijadikan obyek wisata, tetapi ada beberapa kendala yang harus segera ditangani terlebih dahulu, antara lain : sarana jalan yang di beberapa destinasi wisata masih kurang layak, infrastruktur pendukung dan sarana informasi tentang obyek wisata baru masih terbatas, produk lokal yang dihasilkan masyarakat setempat di lokasi wisata masih terbatas, sehingga perlu lebih ditingkatkan lagi.."

Pendapat informan penelitian ke 5 (masyarakat), terkait dengan pelestarian nilai kearifan lokal dalam bentuk bangunan ciri khas perkebunan, yang menjadi daya tarik tersendiri sebuah desa wisata, yaitu sebagai berikut :

..."Salah satu bentuk kearifan lokal yang terlihat disini adalah bentuk perumahan PTP XII khas perkebunan yang unik dengan cirinya masing-masing, tetapi sayangnya di beberapa bagian sudah tampak kurang menarik karena banyak kerusakan sehingga butuh upaya perbaikan.."

\section{PEMBAHASAN}

\section{Strategi Pengembangan Produk Pariwisata Kreatif}

Hasil kegiatan penelitian yang dilakukan di lapangan menunjukkan bahwa strategi pengembangan dilakukan dengan menggunakan web dari Kelompok Sadar Wisata (POKDARWIS) terkait dengan potensi pariwisata yang ada di desa wisata, melakukan kegiatan promosi dengan memanfaatkan media online dan offline, mengadakan berbagai event wisata, membuat lomba produk antar UMKM lokal, melakukan inovasi untuk berbagai kegiatan atraksi wisata dan produk kreatif lokal, pembuatan identitas dan ikon Gucialit sebagai desa wisata, pelestarian kesenian dan kearifan lokal desa, pembuatan web untuk promosi pariwisata desa, menciptakan dan melakukan eksplorasi pariwisata misalnya pembuatan agrowisata, dengan keunggulan wisata alam, wisata sejarah, wisata edukasi, sehingga menjadi sumber pendapatan bagi masyarakat sekitar.

Strategi yang dikembangkan untuk menciptakan produk pariwisata kreatif dilakukan dengan tujuan agar target dan rencana dari pemerintah desa guna mendukung program pemerintah tentang desa wisata bias terwujud. Pembuatan web tentang pariwisata dilakukan oleh Kelompok Sadar Wisata (POKDARWIS), 
pemerintah desa dan Dinas Kebudayaan dan Pariwisata Kabupaten Lumajang, dengan maksud sebagai media pusat informasi kegiatan pariwisata dan industri kreatif yang dilakukan di desa tersebut agar bisa dipromosikan sekaligus sebagai peluang bagi desa untuk meningkatkan jumlah kunjungan wisatawan. Penggunaan media online dan offline dilakukan dengan memanfaatkan media sosial yang memiliki dampak paling besar dalam mempromosikan potensi wisata desa, iklan tentang potensi wisata menggunakan media televise melalui indovision tentang potensi pariwsata yang dimiliki oleh masing-masing daerah.
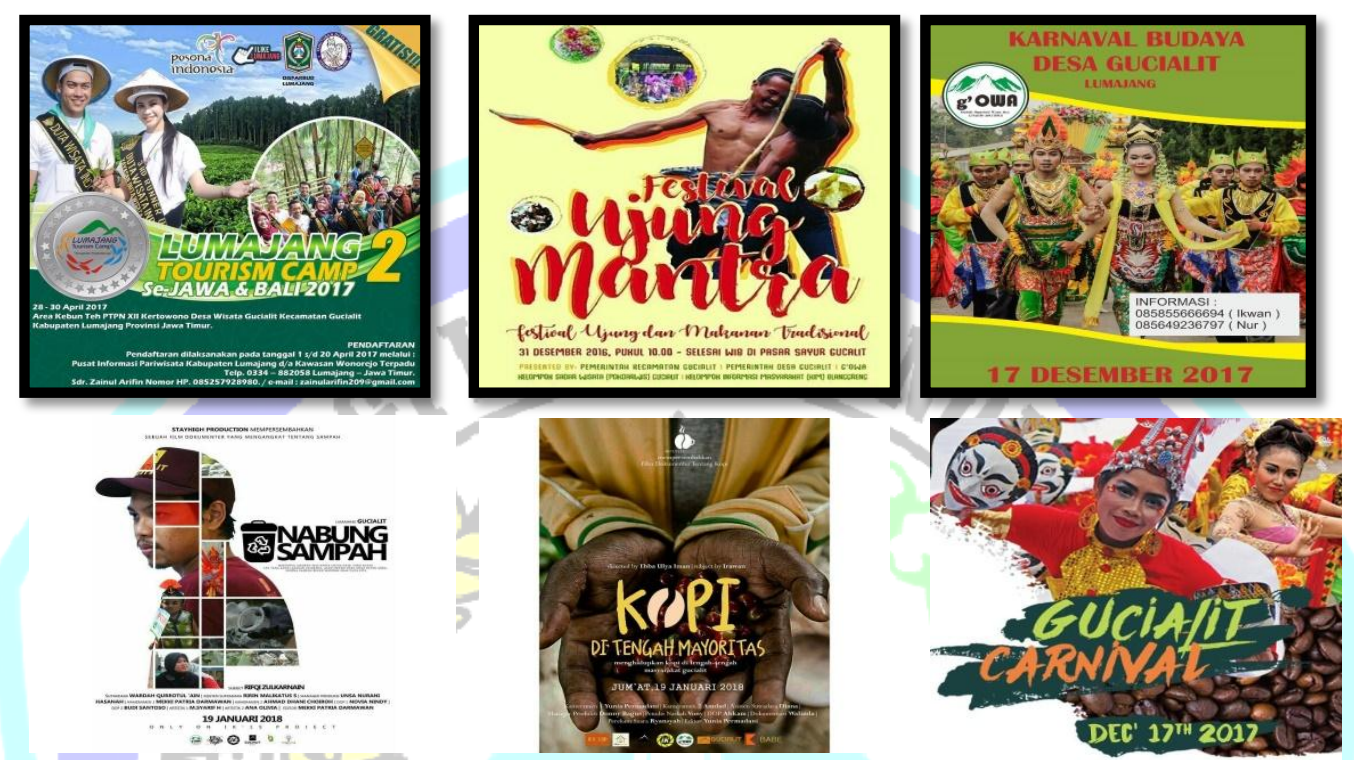

\section{Gambar 1 Strategi Pengembangan Berbasis Media dan Event Wisata Sumber : Dokumentasi GOWA}

Pengadaan lomba inovasi produk antar UMKM lokal, yang dilaksanakan di desa dengan maksud untuk memotivasi masyarakat agar lebih kreatif dan inovatif dalam mengembangkan potensi produk dengan bahan baku lokal yang dimiliki, produk yang sudah dibuat oleh masyarakat meskipun dalam bentuk yang sederhana, tetapi sudah mampu menjadi produk unggulan karena hasil dari inovasi yang dilakukan dengan memaksimalkan potensi desa yang dimiliki, salah satunya adalah produk teh manten dan batik khas dari desa Gucialiat

Pembuatan identitas dan icon Gucialit sebagai desa wisata, dibuat untuk memperjelas sekaligus sebagai penguat citra dan identitas desa dengan lambang guci sebagai nama dari desa yaitu Gucialit dan pohon teh, sebagai icon produk unggulan desa yaitu teh yang dihasilkan oleh PTPN XII Kertowono, karena daya tarik utama dari Gucialit identik dengan perkebunan tehnya dan teh sebagai produk unggulan yang sudah standart eksport.

Pelestarian kesenian dan kearifan lokal desa, dengan kesenian khas ronang dan ujung mantra serta kegiatan eksplorasi pariwisata misalnya pembuatan agrowisata, dengan melakukan senergi dengan berbagai pihak untuk saling bekerja sama yaitu pihak PTPN XII, POKDARWIS, GOWA dan juga masyarakat sekitar, menjaga dan melestarikan berbagai obyek wisata yang dimiliki, antara lain : wisata alam, wisata sejarah, wisata edukasi, sehingga menjadi sumber pendapatan bagi masyarakat sekitar sekaligus sebagai peluang usaha baru yang produktif bagi masyarakat

Sedangkan hambatan yang dialami terkait dengan perlu adanya regenerasi khususnya bagi para pelaku seni atau penggiat seni desa perlu dilakukan agar 
kesenian tradisional khas desa tetap bisa dilestarikan dan diturunkan dari generasi ke generasi, karena selama ini kesenian tersebut hanya di dominasi oleh generasi yang sudah tua, generasi muda masih banyak yang belum tertarik untuk memperdalam kesenian tersebut, sehingga diperlukan adanya sosialisasi serta difasilitasi atau diberikan peluang adanya sanggar seni lokal sebagai media bagi regenerasi tersebut agar potensi seni dan tradisi yang menjadi keunikan sekaligus daya tarik desa masih bisa terjaga keberadaannya.

Masyarakat Gucialit dalam memberikan respon atas dicanangkan sebagai desa wisata akan berhasil secara lebih maksimal, apabila masyarakat yang berada di dalamnya bukan hanya bertindak sebagai penonton melainkan sebagai pelaku utama harus bisa mempersiapkan diri secara lebih baik, karena dengan dijadikan sebuah desa sebagai desa wisata, dampak yang ditimbulkan akan sangat kompleks di berbagai bidang yang salah satunya adalah bagi masyarakat sebagai akibat dari banyaknya wisatawan yang berkunjung ke desa wisata tersebut, sehingga peran sapta pesona mutlak harus dilaksanakan agar desa wisata yang direncanakan bisa berhasil dilaksanakan.

\section{Potensi Sumber Daya Alam dan Kearifan Lokal yang Dimiliki Desa Wisata.}

Potensi Sumber Daya Alam yang dimiliki oleh desa wisata Gucilait, antara lain : wisata kebun teh, wisata air terjun, wisata edukasi, wisata sejarah, wisata budaya, wisata minat khsusus, agrowisata dan beberapa destinasi wisata baru yang masih dalam rencana pengembangan, misalnya wisata outbond, wisata lainnya. Berbagai jenis wisata yang dikembangkan di desa tersebut ada yang sudah lama dikembangkan tetapi ada juga yang masih baru, sehingga masih membutuhkan dukungan dalam bentuk sarana dan prasarana agar destinasi wisata yang ada tetap menarik untuk dikunjungi wisatawan

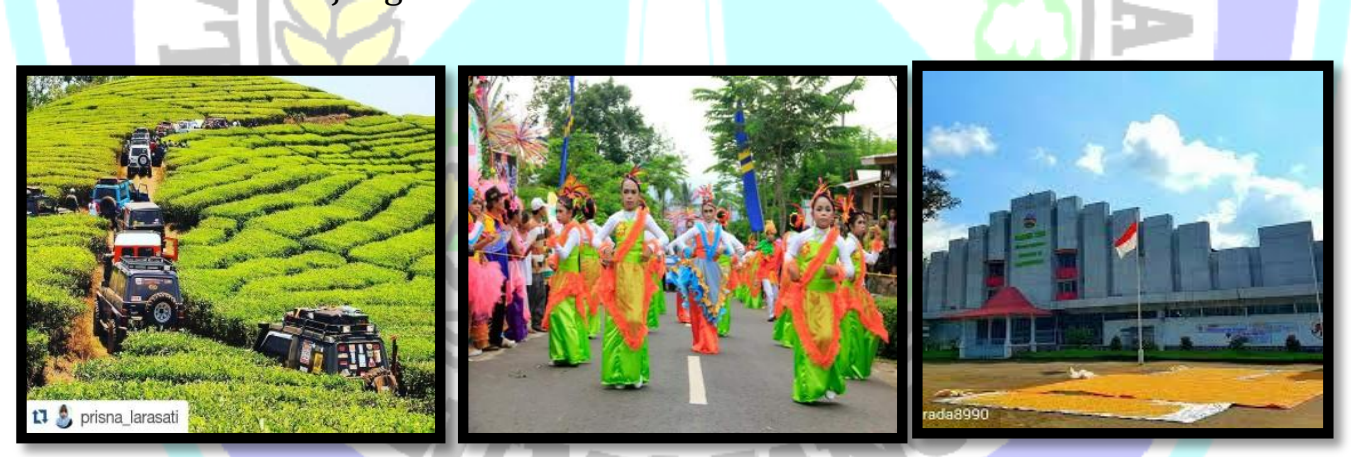

\section{Gambar 2. Berbagai Jenis Wisata di Desa Wisata Gucialit Sumber : Dokumentasi GOWA}

Beberapa bentuk kearifan lokal yang dimiliki oleh desa wisata Gucialit, antara lain : kegiatan karnaval desa, bersih desa, sedekah desa serta masih terjaga kelestariannya adalah sebagai wujud dari rasa syukur atas rezeki dan keselamatan desa tersebut dari musibah yang dilaksanakan secara rutin setiap tahun oleh masyarakat setempat, dan pada moment semacam ini banyak sekali masyarakat maupun wisatawan yang datang berkunjung ke desa tersebut, sehingga event semacam ini memberikan peluang positif bagi kegiatan promosi desa sekaligus sebagai peluang usaha yang menguntungkan bagi masyarakat di desa tersebut. 

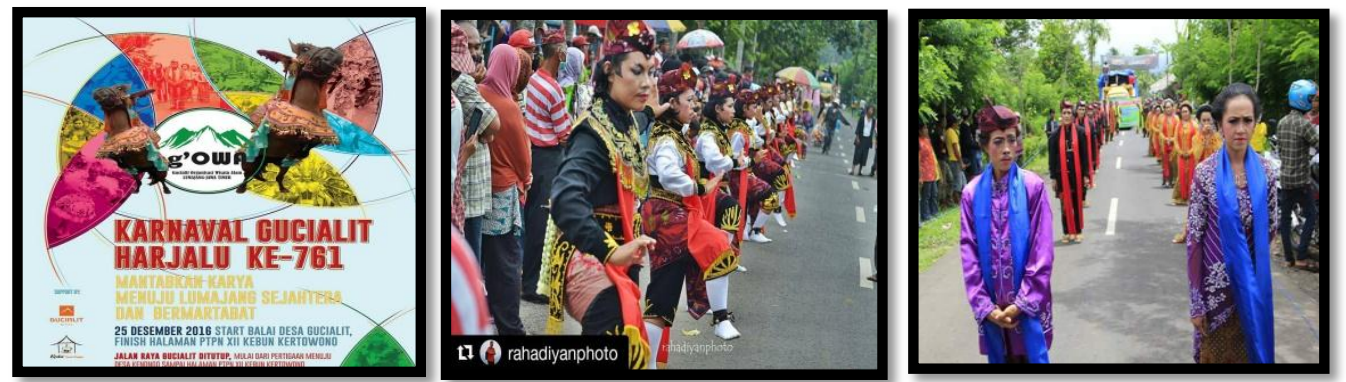

Gambar 3. Kearifan Lokal Desa Wisata Gucialit

Sumber : Dokumentasi GOWA

Bentuk kearifan lokal lainnya yang dimiliki oleh desa wisata adalah adanya bentuk bangunan peninggalan Belanda sebagai sarana rekreasi dan bentuk pemukiman penduduk yang bekerja di PTPN XII Kertowono. Bangunan tersebut masih terjaga kelestariannya sehingga menjadi nilai lebih tersendiri bagi desa wisata tersebut. Fungsi dari beberapa bangunan sudah berbeda dengan awalnya, hanya dibuat lebih rapi, bersih dan menarik. Banyak wisatawan asing khususnya yang dari Belanda memilih untuk menginap di bangunan tersebut, sebagai napak tilas sejarah dan mengingat kembali kenangan masa lalu tentang bangunan tersebut.
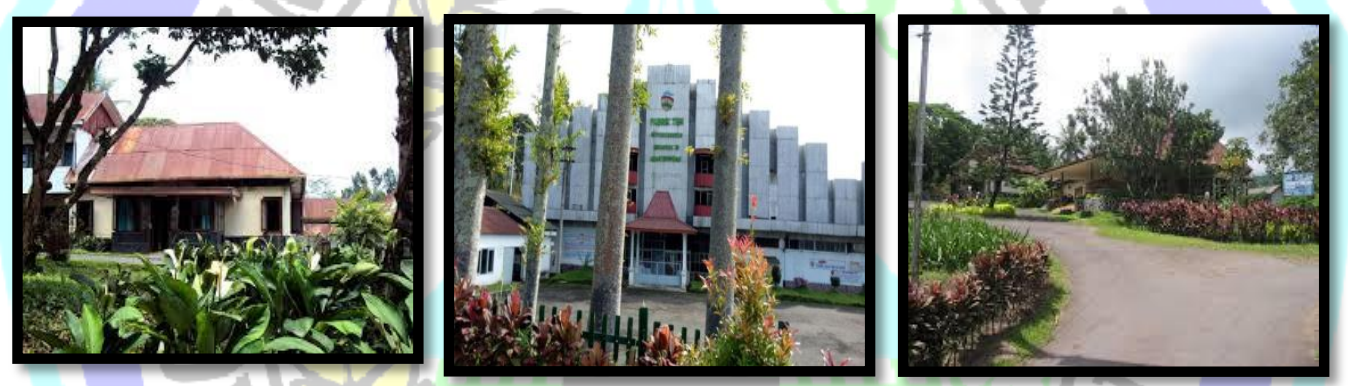

Gambar 4. Bangunan Peninggalan Belanda di PTPN XII Kertowono Gucialit Sumber : Dokumentasi GOWA

Berbagai potensi yang dimiliki baik produk pariwisata kreatif, sumber daya alam dan kearifan lokal yang dimiliki, beberapa diantaranya memiliki kendala dalam hal saran dan prasaran pendukung khususnya bagi destinasi wisata baru, misalnya akses jalan yang dimiliki beberapa di antaranya masih belum beraspal, dan dukungan produk kreatif yang masih terbatas, sehingga perlu dipersiapkan lebih matang lagi sehingga kelengkapan sarana dan prasarana yang dimiliki dapat menunjang kenyamanan dari wisatawan ketika berkunjung ke desa wisata tersebut, sedangkan kondisi perumahan karyawan di PTPN XII Kertowono, menjadi daya tarik lainnya dari kearifan lokal di desa wisata harus lebih ditingkatkan lagi, karena keberadaan rumah perkebunan dengan ciri khasnya masing-masing menjadi peluang bagi wisatawan untuk lebih mengenal sejarah, edukasi khusus terkait dengan bentuk perumahan khas di wilayah perkebunan

\section{PENUTUP}

\section{Simpulan}

Berdasarkan perumusan masalah dan hasil pembahasan sebelumnya, maka kesimpulan yang bisa diambil adalah sebagai berikut :

1. Strategi pengembangan produk pariwisata kreatif, dilaksanakan dengan menggunakan berbagai strategi baik dengan dengan memanfaatkan media online dan offline, serta terdapat beberapa jenis produk unggulan yang dihasilkan oleh 
Usaha Mikro Kecil Menengah (UMKM) di desa tersebut yaitu teh manten, batik, dan kopi senduro, serta desa Gucialit sering dijadikan event bazar dan promosi produk unggulan maupun dari sektor pariwisatanya. Kesiapan dari masyarakat desa untuk daerahnya dijadikan sebagai desa wisata membutuhkan sosialisasi secara lebih intens, masyarakat bukan hanya sebagai penonton, melainkan juga sebagai pelaku utama, agar program pemerintah desa untuk menjadikan desa Gucialit sebagai desa wisata bisa berhasil dilaksanakan

2. Potensi Sumber Daya Alam (SDA) dan kearifan lokal yang dimiliki desa wisata Gucialit cukup beragam selain dari sisi wisata alam sebagai bonus wilayah dan juga berbagai jenis wisata lainnya yang menarik untuk dikunjungi, sarana dan prasarana wisata salah satunya akses transportasi jalan, memerlukan perhatian khusus karena akses jalan yang layak membantu memudahkan wisatawan menuju ke lokasi wisata dan untuk obyek wisata yang baru diciptakan kegiatan promosi secara aktif dan kontinyu perlu dilakukan, sedangkan khususnya untuk wisata budaya membutuhkan perhatian yang lebih serius karena regenerasi terkait dengan pelaku budaya dan penggiat budaya masih perlu dilakukan, sehingga nilai kearifan lokal desa terutama dari segi budaya bisa tetap dilestarikan oleh masyarakat.

\section{Saran}

Berdasarkan hasil kesimpulan sebelumnya, maka saran yang bisa diberikan adalah sebagai berikut:

1. Produk pariwisata kreatif yang dimiliki oleh desa wisata, harus ditingkatkan lagi dengan melakukan terobosan dan baru bukan hanya dari sisi produk, melainkan juga strategi pemasaran yang digunakan, sehingga potensi produk lokal yang dimiliki, bisa dijadikan peluang usaha baru yang produktif untuk dikembangkan

2. Potensi Sumber Daya Alam (SDA) dan kearifan lokal yang dimiliki desa wisata hendaknya harus selalu dijaga, baik dari sisi sejarahnya, ciri khas budaya lokal yang dimiliki serta dari segi budaya yang dimiliki salah satunya adalah pelestarian bentuk perumahan perkebunan yang ada di PTPN XII Kertowono, dengan keunikan yang dimiliki, sehingga menjadi menarik bahkan memberikan suasana baru yang khas dari perumahan di daerah perkebunana sehingga kebutuhan terkait regenerasi budaya untuk pelestarian budaya menjadi hal yang penting dan urgen untuk segera dilakukan

\section{DAFTAR RUJUKAN}

Fathiyah dan Hiryanto (2010), Local Wisdom Identification on Understanding Natural Disaster Sign by Elders in Daerah Istimewa Yogyakarta : Media Informasi Penelitian Kesejahteraan Sosial. Vol.37, No.1, Maret 2013, hal. 453462.

Kostopoulou, S. (2013). On the Revitalized Waterfront: Creative Milieu for Creative Tourism. Sustainability, 5(11), 4578 - 4593.

Muljadi dan Andriwarman, (2014), Kepariwisataan dan Perjalanan, Edisi Revisi Penerbit : PT. Raja Grafindo Persada : Jakarta

Ohridska-Olson, R., \& Ivanov, S. H. (2010). Creative Tourism Business Model and Its Application in M. Damayanti, Latifah/ JPK Vol. 3 No. 2 (2015) 100 - 111111 
Bulgaria. Paper presented at the The Black Sea Tourism Forum 'Cultural Tourism - The Future of Bulgaria, Bulgaria. http://ssrn.com/abstract=1690425

Prawironegoro dan Rivai (2015), Manajemen Strategi. Alfabeta : Jakarta

Sugiyono. (2014), Metode Penelitian Kuantitatif, Kualitatif dan R\&D ( Research and Development ), Penerbit Alfabeta : Bandung

UNESCO. (2006). Towards Sustainable Strategies for Creative Tourism. Retrieved from Santa Fe: UNESCO

Yoeti, Oka. (2008), Pengantar Ilmu Pariwisata. Penerbit Angkasa : Bandung

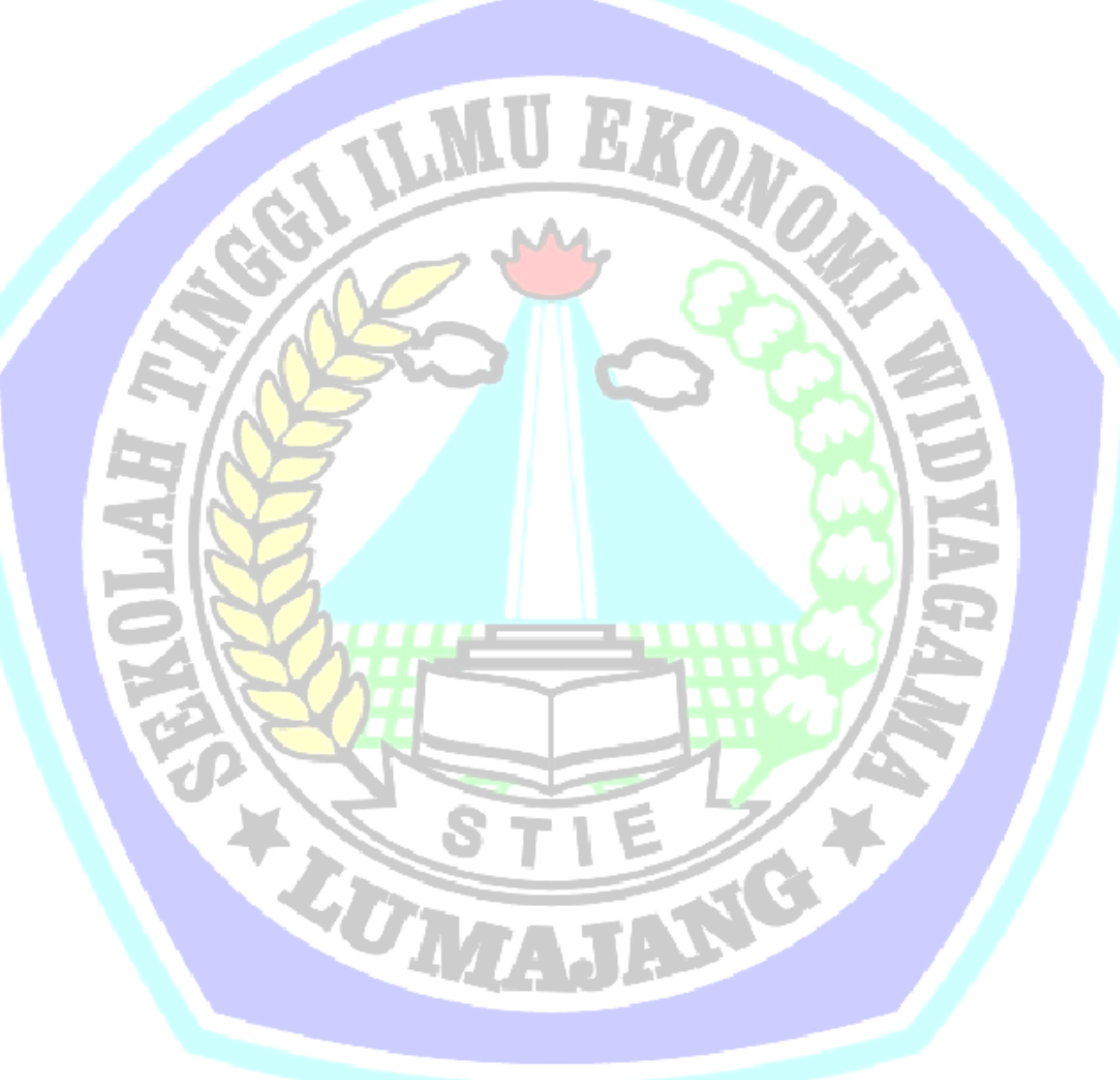

